\title{
Proofing banana blossom (Musa acuminata) water-soluble extract as histamine forming anti- bacteria
}

\author{
Hartati Kartikaningsih ${ }^{1,2 *}$, I. Yahya ${ }^{1,2}$ Lina Asmara Wati $^{3}$, Supriyadi Supriyadi ${ }^{4}$, Rhytia Ayu \\ Christianty Putri ${ }^{5}$, and Rika Kurniaty ${ }^{6}$ \\ ${ }^{1}$ Laboratory Food Safety Faculty of Fishery and Marine Science Brawijaya University, Indonesia \\ ${ }^{2}$ Bioseafood Research Group Faculty of Fishery and Marine Science Brawijaya University, Indonesia \\ ${ }^{3}$ Fisheries Agrobusiness Faculty of Fishery and Marine Science Brawijaya University, Indonesia \\ ${ }^{4}$ PSDKU of Fisheries Socio-economic, Faculty of Fisheries and Marine Science, Brawijaya University, \\ Indonesia \\ ${ }^{5}$ Agricultural Technology Faculty of Agricultural Technology Brawijaya University, Indonesia \\ ${ }^{6}$ Department of International Law Faculty of Law Brawijaya University, Indonesia
}

\begin{abstract}
Banana blossom is a type of vegetable that can be used as a source of fiber. The previous studies showed that the addition of banana blossoms to the baby tuna shredded caused a decrease in the number of microbes compared to control. Histamine-forming bacteria in baby tuna originated from indigenous bacteria and contaminants such as Escherichia coli, Pseudomonas aeruginosa, Klebsiella pneumonia, and Lactobacillus plantarum. This study was aimed to find out how much water-soluble extract of banana blossom anti-bacterial against histamine-forming bacteria. Testing of anti-bacterial ingredients in banana blossom Musa acuminata water-soluble extract with LC-HNMR, toxicity testing, and amino acid testing. The studies using the Kirby Bauer method and corroborated by SEM observations showed that water-soluble extract of banana blossom Musa acuminata had low anti-bacterial properties for Lactobacillus plantarum and Klebsiella pneumonia but not for Escherichia coli and Pseudomonas aeruginosa. Further testing of the anti-bacterial substance water-soluble extract of banana blossom was histidine, proline, isoleucine, threonine, and glutamic acid. This extract categorized as a non-toxic substance
\end{abstract}

\section{Introduction}

Banana blossom is a non-conventional food, and it is often considered as agricultural waste, non-economical vegetables though it is actually a traditional vegetable of the Indonesian people, especially the Javanese. In India, the banana blossom is an ethnic Assamese cuisine for religious ceremonies at Assamese people [1]. In the Philippine's banana blossom is known as "sisig" vegetables [2]. In Indonesia, the banana blossom is generally used as a fibre enhancer in fish shredded [3-5], chicken shredded [6] filler in catfish floss [7], additional ingredients for chicken nuggets [8]. Research on flour of banana blossom used on cake dough

\footnotetext{
* Corresponding author: hartatikartikaningsih@gmail.com
} 
made [9], chocolate cookies [10], and biscuit [11]. The active ingredient in banana blossom is used as a medicine for dysentery, ulcer and bronchitis [12], antioxidant [13-16]; antimicrobial [17-21], anti-cancer [22], anaemia medicine [23], medium for Cryptococcus gathiil [24], diabetes medicine [10, 25-26].

Our previous study on the addition of banana blossom in baby tuna shredded showed a decrease in histamine content (unpublish data). Histamine is the decarboxylation of histidine by some histamine-forming bacteria, including Morganella morganii, Klebsiella pneumoniae, Pseudomonas aeruginosa, indigenous bacterium in fish and contaminants bacteria such as Escherichia coli and Salmonella thyposa. The banana blossom should be boiled first before being used as filler fish shredded. No much information about the watersoluble extract of banana blossom as anti-bacteria against histamine-forming bacteria. Antibacterial banana blossom used ethanol extract was observed by [19, 22, 27-29]. Banana blossom methanol extract was studied by [13]. The research aimed to know the anti-bacterial of a water-soluble extract of banana blossom against histamine-forming bacteria.

\section{Materials and methods}

\subsection{Preparation of water-soluble extract of banana blossom}

The red sheets of banana blossom were discarded until the yellow sheets were seen. Banana blossom are cut roughly, boiled for 15 minutes at $100^{\circ} \mathrm{C}(1 ; 3 \mathrm{w} / \mathrm{v})$, drained using krischef noodle filter for a while, and ground used a blender (Philip HR 115), and separated liquid and solid of the bud using tea filter. The liquid of that banana bud was the sample to be analyzed for its antibacterial ability, toxicity assay, LC-HRMS and amino acids composition. The antibacterial ability of water-soluble extract of banana blossom was also observed on electron microscopy.

\subsection{Toxicity assay}

Toxicity assay used $\mathrm{LC}_{50}$ of Artemia salina. $2 \mathrm{~g}$ of the cyst of Artemia salina eggs (Brine shrimp Egg) was placed in a container filled with seawater $\pm 30 \mathrm{ppt}$ at room temperature \pm $29^{\circ} \mathrm{C}$ for 48 hours to hatch and separate the nauplii and the eggshell. Water-soluble extract of banana blossom diluted with Dimetil Sulfoksida (Sigma-Aldrich CAS 67-68-5) with a concentration of $1,10,100,1000 \mathrm{mg} / \mathrm{ml}$. 8-well plate cell culture (ThermoFisher scientific 167064) filled with $5 \mathrm{ml}$ of seawater. According to the experiment, every two wells filled with banana blossom extract is as much as $100 \mu$ l. The negative control used well plate cell culture filled with Dimetil Sulfoksida $100 \mu$ l. Every well plate cell culture was filled with 40 nauplii for 24 hours. All of the wells were observed under a binocular microscope (Olympus Cx-23 LED) to check the living of nauplii. The nauplii were not shown movement during the observation categorized as dead. The mortality was calculated using the formula:

$$
\text { Mortality }(\%)=\frac{\text { Number of dead nauplii }}{\text { Number of total nauplii }} 100
$$

The percentage of mortality was transformed into a regression pro-bit to count the lethal concentration fifty. $\mathrm{LC}_{50}$ values were obtained from the average calculation of three times of $\mathrm{LC}_{50}$ testing. 


\subsection{Antibacterial activity assay}

P. aeruginosa, K. pneumonia, L. plantarum, E. coli were specimen collections of Microbiology Laboratory Faculty of Medicine, Brawijaya University. Antibacterial activity assay used the disc diffusion testing. Nutrient Agar Medium (Merck 105450) prepared in a sterile condition, plated in Petri-dish. Using the spread plate technique with $100 \mu \mathrm{l}$ of the bacterial strains $\left(10^{7} \mathrm{CFU} / \mathrm{mL}\right)$, let it dry for 15 minutes. Sterile paper disks (Whatman, 6 $\mathrm{mm}$ of diameter) were soaked with $100 \mathrm{ppm}$ of a water-soluble extract of banana blossom then placed on the surface of the plates. The concentration of banana extract solution was reduced by half to $50 \mathrm{ppm}, 25 \mathrm{ppm}, 12.5 \mathrm{ppm}, 6.25 \mathrm{ppm}, 3.125 \mathrm{ppm}$, and $0 \mathrm{ppm}$. Negative control used DMSO solution. All the plates were stored at $4^{\circ} \mathrm{C}, 2$ hours to allow the diffusion of a water-soluble extract of banana blossom to the medium. All the plates then incubated at $37^{\circ} \mathrm{C}$ for 48 hours. The diameter of clear zones $(\mathrm{mm})$ of the paper disk was measured as antibacterial activity.

\subsection{Electron microscope observation}

The microbes from the MIC test were centrifuged $\left(5000 \mathrm{rpm}, 10 \mathrm{~min}, 5^{\circ} \mathrm{C}\right)$. Pellets were washed with PBS, phosphate buffer solution ( $\mathrm{pH} 7.2,1: 10 \mathrm{v} / \mathrm{v})$, vortex, and centrifuge again $\left(5000 \mathrm{rpm}, 10 \mathrm{~min}, 5^{\circ} \mathrm{C}\right)$. Washing and centrifugation of pellet were carried out three times. $10 \mu \mathrm{L}$ of the pellet was dropped on a coverslip, dried at room temperature $\left(2 \mathrm{~h}, 37^{\circ} \mathrm{C}\right) .0 .25 \%$ of glutaraldehyde in PBS ( $\mathrm{pH} 7.2$ ) was added to the coverslip, incubated at room temperature $\left(24 \mathrm{~h}, 37^{\circ} \mathrm{C}\right)$, and then washed again with PBS ( $\mathrm{pH} 7.2,1 \mathrm{~min}$, repeated three times). Ethanol $30 \%, 50 \%, 70 \%, 80 \%, 90 \%$ dan $100 \%$ were added on the coverslip (10 min in each solution) and then incubated at $100 \%$ ethanol for $1 \mathrm{~h}$.

\subsection{Detection of an antibacterial compound using chromatography-high resolution mass spectrometry (LC-HRMS)}

Detection of antibacterial compound of a water-soluble extract of banana blossom using LCHRMS (Thermo Fisher Scientific) was done in Central Laboratory of Life Sciences, Brawijaya University. It used hyper sail gold aQ50 x $1 \mathrm{~mm} \times 1.9 \mu$ particle size of the column. Water-soluble extract of banana blossom was dissolved into methanol (absolute, LCMS grade), vortexed for 3 minutes, spin down 3 minutes, filtered using the minisart filter PTFE (pore size $0.22 \mu \mathrm{mm}$ ). $1 \mathrm{ml}$ of sample injected with $0.1 \%$ formic acid in $\mathrm{H}^{2} \mathrm{O}$ as mobile phase A, and $0.1 \%$ formic acid in acetonitrile as mobile phase B. The flow rate was $40 \mu \mathrm{L} / \mathrm{min}$, running time $30 \mathrm{~min}$, oven column temperature $30^{\circ} \mathrm{C}$. The elution gradient was $0-2 \mathrm{~min} 5 \% \mathrm{~B}$, $15-22 \mathrm{~min} 60 \%$ to $95 \% \mathrm{~B}$ and kept in $95 \% \mathrm{~B}$ for $3 \mathrm{~min}$ then let it down to $5 \% \mathrm{~B}$ at $30 \mathrm{~min}$.

Detection antibacterial component used the compound discover software three based on the online library listed in the mzCloud. To find out the anti-bacterial component of watersoluble extract of banana blossom, the compound had been detected cohering in PubChem page.

\subsection{Amino acids analysis}

The amino acids composition was analyzed at the Laboratory of Life Sciences Brawijaya University using ultra-pressure liquid chromatography. $5 \mathrm{~mL}$ of hydrochloric acid $6 \mathrm{~N}$ was mixed with $0.1 \mathrm{~g}$ samples. All samples were then hydrolyzed at $110^{\circ} \mathrm{C}, 24 \mathrm{~h}$, transferred to $100 \mathrm{~mL}$ distilled water, filtered using $0.45 \mu \mathrm{m}$ filter paper. The $500 \mu \mathrm{L}$ filtrates were mixed with $40 \mu \mathrm{L} 2$-Amino-4 boron butanoic acid and $460 \mu \mathrm{L}$ double distilled water. The $10 \mu \mathrm{L}$ of that solution was mixed with $70 \mu \mathrm{L}$ AccQ Fluorine Borate and $20 \mu \mathrm{L}$ fluorine, vortexed, 
incubated at $55^{\circ} \mathrm{C} 10 \mathrm{~min}$. The solutions were injected into the UPLC system to calculate the composition of amino

\section{Result}

\section{1 $\mathrm{LC}_{50}$ water-soluble banana blossom extract}

$\mathrm{LC}_{50}$ water-soluble extract of banana blossom from three replication can be seen in Figure 1. The regression equation was $\mathrm{Y}=1.389 \mathrm{x}-0.406$ with the $\mathrm{x}$-axis dose logarithm and the $\mathrm{y}$ axis probit value calculated from the percentage of Artemia salina mortality. $\mathrm{Y}=5$ was a count from this equation, then calculated into anti-logarithm as the value of $\mathrm{LC}_{50}$.

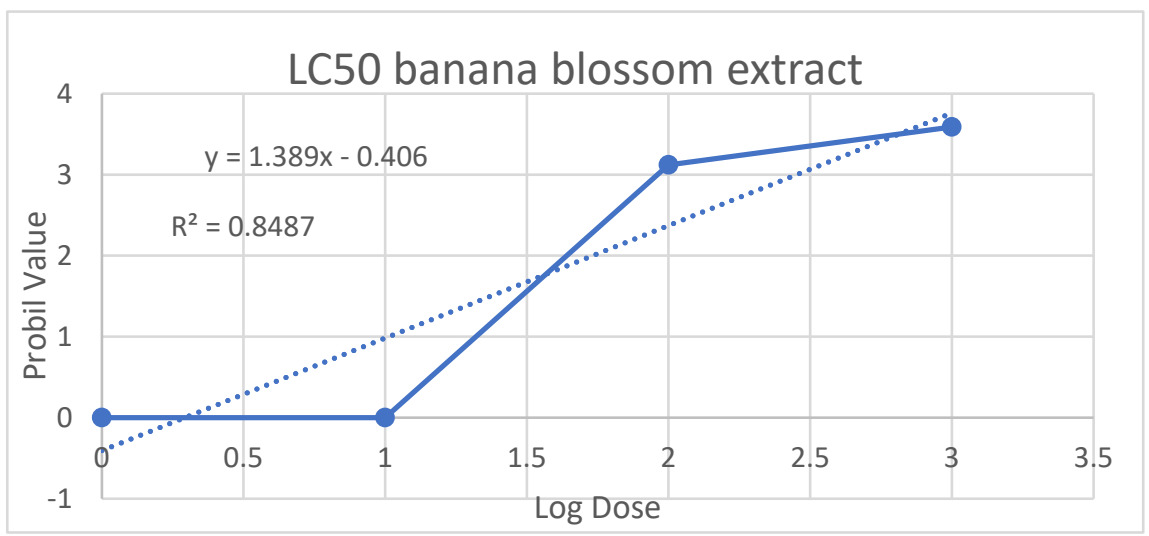

Fig. 1. LC 50 of banana blossom water-soluble extract.

\subsection{The inhibition zone of water-soluble banana blossom extract}

Table 1. Minimum Inhibitory Concentration of Aqua extract of banana blossom.

\begin{tabular}{|l|l|l|l|l|}
\hline $\begin{array}{c}\text { Concentration } \\
(\mathrm{ppm})\end{array}$ & $\begin{array}{c}\text { Klebsiella } \\
\text { pneumonia }\end{array}$ & $\begin{array}{c}\text { Lactobacillus } \\
\text { plantarum }\end{array}$ & Escherichia coli & $\begin{array}{c}\text { Pseudomonas } \\
\text { aeruginosa }\end{array}$ \\
\hline 100 & $6.6 \pm 0.055$ & $7.1 \pm 0.055$ & $6 \pm 0$ & $6 \pm 0$ \\
\hline 50 & $6.0 \pm 0.005$ & $6.6 . \pm 0.05$ & $6 \pm 0$ & $6 \pm 0$ \\
\hline 25 & $6 \pm 0$ & $6 \pm 0$ & $6 \pm 0$ & $6 \pm 0$ \\
\hline 12.5 & $6 \pm 0$ & $6 \pm 0$ & $6 \pm 0$ & $6 \pm 0$ \\
\hline 6.25 & $6 \pm 0$ & $6 \pm 0$ & $6 \pm 0$ & $6 \pm 0$ \\
\hline 3.125 & $6 \pm 0$ & $6 \pm 0$ & $6 \pm 0$ & $6 \pm 0$ \\
\hline 0 & $6 \pm 0$ & $6 \pm 0$ & $6 \pm 0$ & $6 \pm 0$ \\
\hline
\end{tabular}




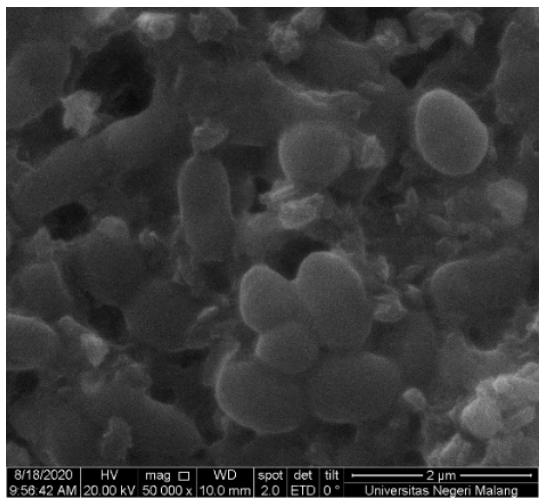

a

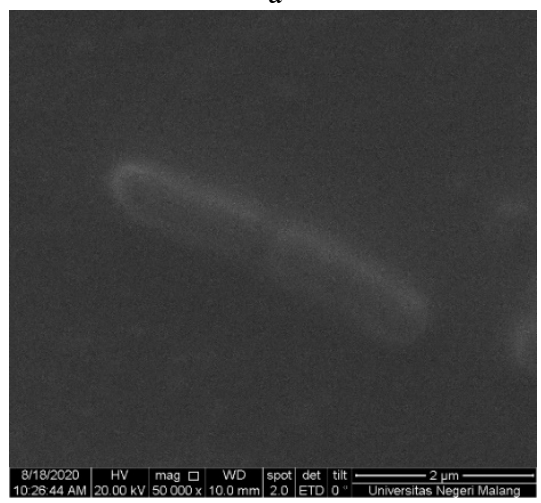

c

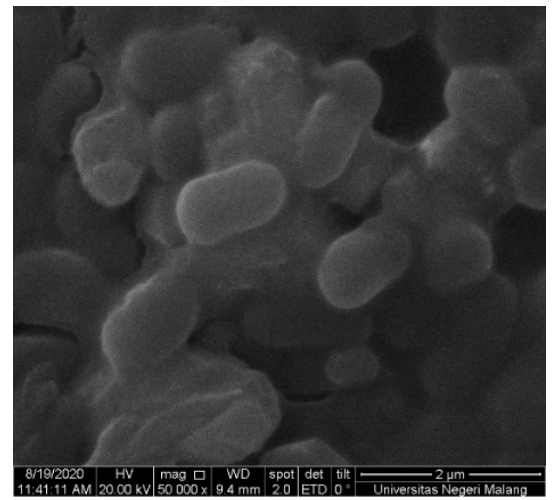

b

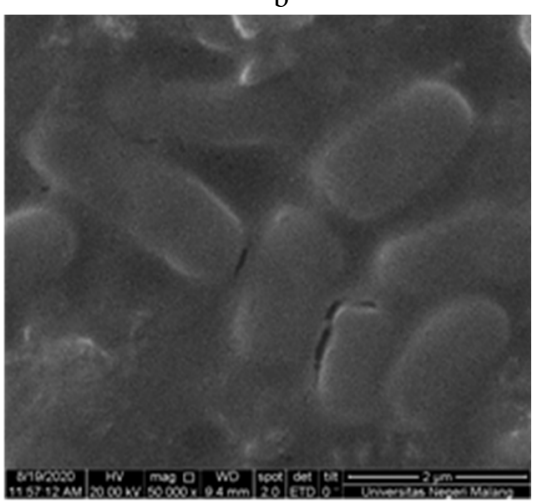

d

Fig. 2. SEM of water-soluble banana extract againt the growth of histamine-forming bacteria (a) Pseudomonas aeruginosa (b) Escherichia coli (c) Lactobacillus plantarum (d) Klebsiella pneumonia, magnified 50000 times.

Banana blossom water-soluble extract up to $100 \mathrm{ppm}$ only slightly inhibited the growth of Klebsiella pneumonia and Lactobacillus plantarum not to Escherichia coli and Pseudomonas aeruginosa as seen at Table 1. The same description of this can be seen in Figure 2.

\subsection{Observation of water-soluble banana blossom anti-bacterial substances}

Form the LC-HRMS can be seen the $\mathrm{m} / \mathrm{z}$ and retention time of the active compound of banana blossom aqua extract as in Figures 3 and 4.18 components had anti-bacterial activity. Of the 18 components, there were seven components at most that matched with the retention time and $\mathrm{m} / \mathrm{z}$ value, as seen in Table 2 . The composition of amino acids of this extract can be seen in Table 3. 


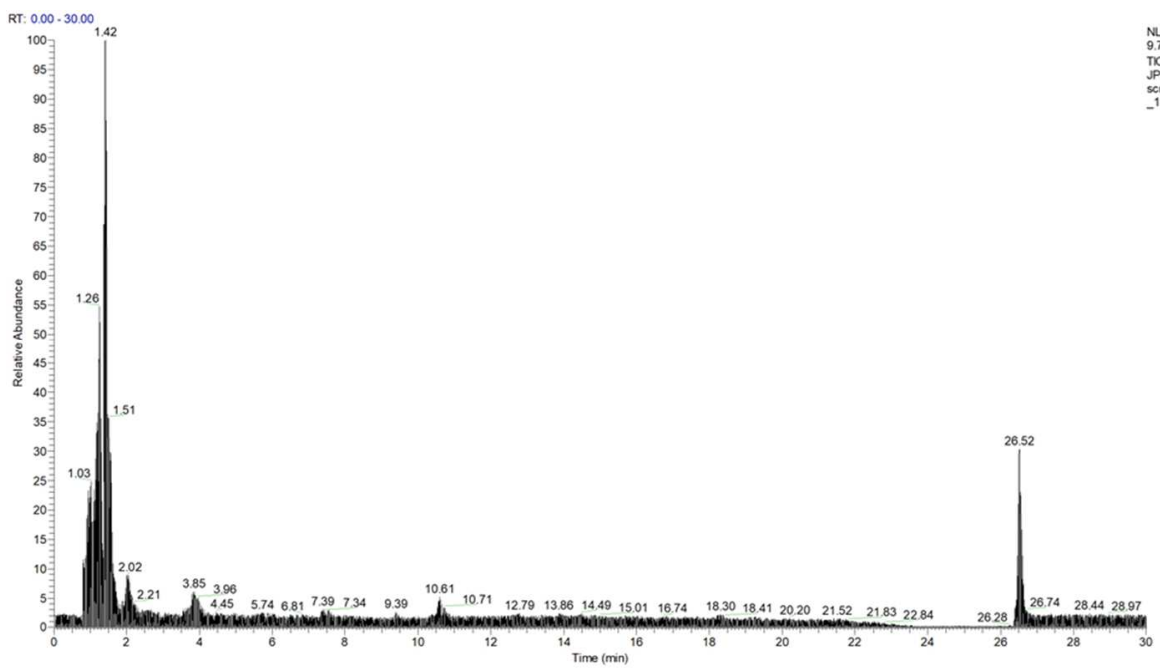

Fig. 3. The retention time the compound of aqua extract banana blossom.

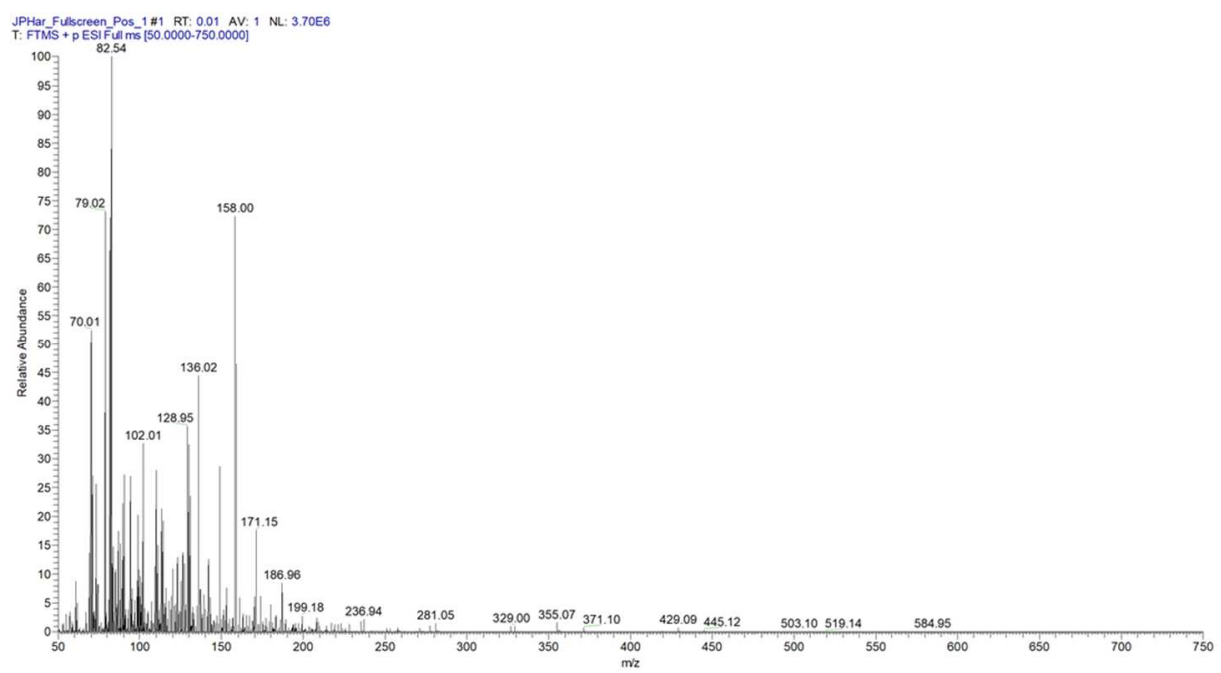

Fig. 4. $\mathrm{m} / \mathrm{z}$ value the compound of aqua extract banana blossom.

Table 2. The main anti-bacterial compound from LC-HRMS.

\begin{tabular}{lllll}
\hline The main compound & $\begin{array}{c}\text { Molecular weight } \\
(\mathrm{g} / \mathrm{mol})\end{array}$ & $\begin{array}{c}\text { Retention } \\
\text { time }\end{array}$ & Mz cloud & Reference \\
\hline Epigallocatechin & 306.07 & 2.61 & 89.8 & https://pubche \\
Abscisic acid & 264.13 & 9.40 & 90.8 & m.ncbi.nlm.nih \\
6-methoxyquinone & 159.07 & 1.92 & 77.3 & gov. Bioassay \\
Crotonid acid & 86.04 & 1.0 & 69.2 & \\
D-serine & 105.04 & 0.87 & 67.2 & \\
Indole & 117.06 & 6.9 & 84.1 & \\
Isoleucine & 131.09 & 1.55 & 89.1 & \\
L-Histidine & 155.07 & 1.26 & 92.7 & \\
L-Pyroglutamic acid & 129.04 & 1.44 & 83 & \\
L-Threonine & 119.06 & 0.89 & 85.9 & \\
Mannitol & 126.03 & 1.99 & 73.5 & \\
Phloretin & 274.08 & 6.69 & 54.9 & \\
Pipecolic acid & 147.09 & 1.39 & 88.4 & \\
\hline
\end{tabular}




\begin{tabular}{llll}
\hline Proline & 133.07 & 1.28 & 92.4 \\
Salicylic acid & 138.03 & 6.69 & 72.2 \\
Triethanolamine & 149.10 & 26.4 & 77.6 \\
Valine & 117.08 & 1.39 & 71.4 \\
Vanillin & 152.05 & 6.49 & 81.8 \\
\hline
\end{tabular}

Table 3. Composition of amino acids from banana blossom (mg/g protein).

\begin{tabular}{lllllllll}
\hline TEAA & Arg & His & Ile & Leu & Lys 0.00 & Phe 0.35 & Thr 0.45 & Val 0.55 \\
3.45 & 0.85 & 0.20 & 0.45 & 0.60 & \pm 0.01 & \pm 0.01 & \pm 0.01 & \pm 0.01 \\
& \pm 0.01 & \pm 0.01 & \pm 0.01 & \pm 0.01 & & & & \\
\hline TNEA & Ala & Asp & Glu 1.98 & Gly 0.84 & Pro & Ser & Tyr 0.0 & \\
4.99 & 0.0 & 1.18 & \pm 0.02 & \pm 0.01 & 0.20 & 0.79 & \pm 0.0 & \\
& \pm 0.00 & \pm 0.00 & & & \pm 0.01 & \pm 0.01 & & \\
\hline
\end{tabular}

\section{Discussion}

$\mathrm{LC}_{50}$ water-soluble extract of banana blossom was $7800 \mathrm{ppm}(7.8 \mathrm{mg} / \mathrm{ml})$ and categorized as a nontoxic substance. Banana blossom is usually consumed as a vegetable, especially in Javanese people. Banana blossom was used as dysentery, diarrheal, and bronchitis medicine [29], as anti-inflammatory [30], anti-yellow fever virus [31], and modulate hypocholesterolaemia and hypoglycaemic [25], so it is often used as food, served as cuisine, food-cooking, and artificial meat. The banana blossom-dried powder can be used as a substitute flour [32]. [13] showed that banana blossom methanol extract had $\mathrm{LC}_{50} 9.97$ $\mathrm{mg} / \mathrm{ml}$. Banana blossom methanol extract and water-soluble extract were nontoxic substances.

Ethanol extract of banana blossom dominated by nonanal (73\%) heptanal $(75 \%)$ and hexanal (5\%) which were the volatile component [33]. The research of [34] showed the active compound of banana blossom ethanol extract were saponin, flavonoid, tannin, phytates, oxalates, and low amount of phenol. The research of [21] showed a similar result, banana blossom ethanol extract consisted of glycoside, saponin, and flavonoid, while banana blossom methanol extract was glycosides, tannins, saponins, phenols, steroids, and flavonoid [13]. Naturally, the flavonoids to be synthetized by plants as responses microorganism attack. This research did not observe the Phyto-chemistry of banana blossom but only based on these thoughts and results of the previous studies that banana blossoms can reduce the number of microbes in shredded baby tuna. The research showed that water-soluble extract of banana blossom had no antibacterial activity against histamine-forming bacteria. It did not inhibit the growth of Escherichia coli and Pseudomonas aeruginosa, but it only had a little bit antibacterial activity against Klebsiella pneumonia and Lactobacillus plantarum. The observation with an electron microscope also showed the same phenomena as seen at Figure 2. The weak anti-bacterial standard was a clear zone of 10-15 mm. In our finding, banana blossom did not belong to the weak anti-bacterial classification. Compared with [17], the presence of benzene sulphonyl chloride $10 \mu \mathrm{l}$ can inhibit the growth of Escherichia coli, Klebsiella pneumonia, and Pseudomonas aeruginosa. Aqueous extract of Musa sapientum peel had weak anti-bacterial activity (range14-17 mm), under standard $23 \mathrm{~mm}$ against Escherichia coli and Pseudomonas aeruginosa [21]. [20] showed that ethyl acetate fraction of banana blossom had phenolic content sufficient as anti-bacterial against Staphylococcus aureus, Streptococcus pyogenes, Escherichia coli and Pseudomonas aeruginosa. [12] showed that banana blossom ethanol extract had medium-weak antibacterial against Proteus vulgaris, Staphylococcus aureus, Salmonella typhi, Pseudomonas aeruginosa, Klebsiella pneumoniae, Bacillus subtilis, and Escherichia coli. It is almost the same result with [19] research, that crude ethanol extract of banana blossom Musa balbisiana colla had antibacterial activity at $6,25 \mu \mathrm{g} / \mathrm{ml}$ against Escherichia coli and Pseudomonas aeruginosa. 
Water-soluble extract of banana blossom did not show to have anti-bacteria of histamine forming bacteria. It dit not indicate that banana blossom aqua extract was inactive nor the absence of active compounds. It is expected that it is insufficient quantitatively of compounds with the dose applied. It can also be caused poor absorption of the active compounds to the cell of microorganisms. [21] showed that there are four main component of Musa sapientum peel ethanol extract and aqueous extract, namely p-coumaric acid ethyl ester, Gallo-catechin, epigallocatechin and vitamin E. Table 2 showed the main component anti-bacterial of a water-soluble extract of banana blossom was amino acids. These were weak acids so only Lactobacillus plantarum was susceptible, as seen in Figure 2 and Table 1. The same result was shown by [31] that aqueous extract of banana blossom is less likely to dissolve the antimicrobial compound. The research of [16] showed that anti-bacterial from banana blossom was 2-amnio-arylthiazole. This compound was anti-bacterial against bacteria Gram-positive and slightly effective for Klebsiella pneumonia but not for Escherichia coli.

Water-soluble extract of banana blossom had TEAA (total essential amino acids, and TNEAA (total non-essential amino acids). Table 3 confirmed the LC-HRMS testing that the anti-bacteria compound of banana blossom aqueous extract was amino acids group. The research of [35] showed that the main compound of banana blossom extract was glutamic acids. Glutamic acid of the water-soluble banana blossom extract was the highest content of this extract. From the amino acid content compared with $\mathrm{m} / \mathrm{z}$ cloud value, the levels of these amino acids highest order of $\mathrm{m} / \mathrm{z}$ cloud were histidine, proline, isoleucine, threonine, and glutamic acids, followed valine, and the lowest was serine. The protein content of proline and histidine had low enough (Table 3). Isoleucine and threonine had protein content more than proline and histidine. It was presumed that the anti-bacterial of a water-soluble extract of banana blossom can only slightly inhibit the growth of Lactobacilus plantarum caused by low levels of these amino acids. Aqueous extract of banana blossom had an anti-bacterial component, but it was not strong enough to penetrate the peptidoglycan of cell bacteria forming histamine

\section{Conclusion}

Water-soluble extract of banana blossom was a weak anti-bacterial for Lactobacillus plantarum and had no anti-bacteria for bacteria forming histamine. The main components of anti-bacterial were histidine, proline, isoleucine, threonine, glutamic acid.

\section{References}

1. U. Sarma, V.K Govila, A Yadav, J. Ethn. Foods 7, 1-7 (2020)

2. I.F. Salvador, International Conference on Agribusiness Marketing, 321-335 (2012)

3. N. Rohmawati, A.D Moelyaningrum, E. Witcahyo. Warta Pengabdi, 12, 92-101 (2019)

4. F.L. Amir, N.W.R Mariani, International Conference on Tourisme Gastronomy and Tourist Destination (ICTGTD), 195-199 (2018)

5. Jusniati, P. Kadirman, J. Pendidik. Teknol. Pertan. 3, 58-66 (2017)

6. N. Novidianto, O.P Enardi, A. Devriany, A.P Pratiwi, M Airuni. Amerta Nutr, 4, 299$306(2020)$

7. W.W Perdana, W. Widowaty. D.R Sofia, Y. Setiawan, D. Hadayanti, A. Zakaria. Annual Conference on Science Technology (ANCOSET), 1869 (2021)

8. W. Sartika, E. Rahmi, International Conference on Animal Producttion for Food Sustainability: Earth and Environmental Science, 287 (2019)

9. T. Tasnim, P.C Das, A.A Begum, A.H Nupur, A.R Mazumder, J. Agric. Food. Res. 2, $1-8(2020)$ 
10. Komal, P. Kaur, Int. J. Trend Res. Dev. 3, 1930-1931 (2019)

11. N. Lal, N. Sahu, G. Siukar, D.K. Jayswal, S. Chack, J. Pharm Innov. 6, 223-228 (2017)

12. V.V Krishna, K.G Kumar., K. Pradeepa, S.R.S Kumar, K. Vijay, Int. J. Pharm. Sci. Drug. Res. 5, 67-69 (2013)

13. V.Sumathy, S.J. Lachumy, Z. Zakaria, S. Sasidharan, Pharmaco 2, 118-127 (2011)

14. J. Joseph, D. Paul, M.P Kavitha, B. Dineshkumar, J. S Menon, A.R Bhat, K.K. Kumar. J. Pharm. Res. 8,144-147 (2014)

15. A.S Khrisnan, V.R Sinija, Int. J. Agric. Food. Sci. Tech. 7, 13-22 (2016)

16. M.A Jalal, W.A Radhi, J. Basrah Res. Sci. 43, 72-85 (2017)

17. B.C. Chinyere, O.C Uchechukwwu, U. Collins, N.O Kieran, Int. Lett. Chem. Phys. Astron.70, 42-47 (2016)

18. A.G Ogofure, A.O Emoghene, NJAFE. 12, 19-26 (2016)

19. H.T Ly, V.M Le, M.T Nguyen, T.H Pham, H.D Nguyen, M.K Nguyen, Pharm. Sci Asia 48, 388-401 (2021)

20. M.M Ariffin, H.Y Khong, N. Nyokat, G.M Liew, A.S Hamzah, K. Boonpisuttinant, J. Appl. Pharm. Sci 11, 91-99 (2021)

21. P. Sangavi, R. Rajapriya, S. Firthous, K. Langeswaran, G.S Kumar, Res. J. Biotech. 16, 180-196 (2021)

22. V. Virabhakul, K. Sutthhanut, Graduate Research Conference, 803-812 (2012)

23. S. Anand, M. Sharma, Plant Arch. 20, 114-117 (2020)

24. K. Khayhan, S. Juntaboon, W. Fang, T. Chaowasku, D. Amorthipayawong, T. Boekhout, Mycoses 1, 1-4 (2018)

25. R. Liyanage, S. Gunasegaram, R. Visvanathan, C. Jayathilake, P. Weththasinghe, B.C Jayawardana, J.K Vidanarachchi, Cholesterol 6, 1-6 (2016)

26. I.S. Salem, A.A Ameen, M.S Mohammed, Egypt J. Nutrition 33, 89-110 (2018)

27. Z.A.G Chabuk, A.H. Al-Charrakh, N.K.K. Hindi, S.K.K. Hindi, Pharm. Series 1,73-75 (2013)

28. L. Evbuomwan, I.B. Jacob, G.O Onodje, C.E Patrick, Int. J. Novel Res. Life Sci 5, 26$31(2018)$

29. R.S. Jouneghani, A.H.F Castro, S.K Panda, R. Swennen, W. Luvten, Food. 9, 1-19 (2020)

30. L.P. Sandjo, M.V.P dos S. Nascimento, M.H. Moraes, L.M. Rodrigues, E.M Dalmarco, M.W Biavatti, M Steindel, Molecules 24, 1-9 (2019)

31. S.K. Panda, A.H.F. Castro, R.S. Jouneghani, P. Leyssen, J. Neyts, R. Swennen, W. Luyten, Viruses 12, 1-17 (2020)

32. K.A.A Chowdhury, S.M.Z Hosen, M.N. Islam, I Huq, M.A Mohammed, N Uddin, I. Kabir, RbinJ Auniq, R. Uddin, M. Shoibe, M.A.G Chowdhury, The Pharma Innov. J. 5, 97-100 (2016)

33. Y. Wang, $\mathrm{X}$. Wang, $\mathrm{F} \mathrm{Xu}, \mathrm{H}$. Wu, International Conference on Engineering and Technology Innovation (ICETI), 263-268 (2016)

34. A.T Adeolu, D.O Enesi, Int. Res. J. Plant Sci. 4, 7:192-197 (2013)

35. T.A Ndaburu, O.N Rosemary, J.A Gboke, G. David, S. Binta, Z. Rukiya, S.I. Zungeru, Biomed. Nat. Appl. Sci. 1, 32-42 (2021) 